\title{
鉄鋼 ニューズ
}

\section{昨年のわが国鉄銅生産}

日本鉄鈵連盟は，このはど昨年 1〜12月分の鉄鋼生産 量さ集計したが，それによれば制は $28,273 千 \mathrm{t}$ で，一 昨年に比べ $27 \cdot 7 \%$ の伸びになつて拈り，英国む抜いて 世界等 4 位に躍進することは一段と確実になつた。また 昨年 1〜12月の銑鉄生産量は 15,815千 t で，一昨年に

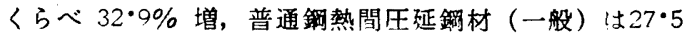
\%増の 19,564 千 $\mathrm{t}$ ，特殊銅熱間圧泟鎆材は $25.6 \%$ 増の 1,489千 t となつている.

昨年 1 〜 12 月の鉄銅生産の概要は次の通り（単位千 $\mathrm{t}$ 対 35 年比率\%)

○鋎鉄

高炉鋴 $15,659 \quad 133.6$ 電気鋩 $518 \quad 106 \cdot 9$ その他銑 $238 \quad 168 \cdot 8$ 計 $15,815 \quad 132 \cdot 9$

○粗鋮

\begin{tabular}{|c|c|c|c|c|c|}
\hline 平炬鎆 & 16,966 & $112 \cdot 8$ & 転炬鋼 & 5,362 & $204 \cdot 0$ \\
\hline 電炬鋼 & 5,945 & $133 \cdot 2$ & 計 & 28,273 & $127 \cdot 7$ \\
\hline \multicolumn{4}{|c|}{ ）普通鋼熱間圧延鋼材（一般） } & 19,564 & $127 \cdot 5$ \\
\hline \multicolumn{4}{|c|}{ 特殊銅熱間圧延鋼材 } & 1,469 & $125 \cdot 6$ \\
\hline
\end{tabular}

\section{1年の世界粗糔生産}

日本鉄鋼連盟の調へによれば，1961年の世界粗鋼生産 は, 1960年にくらべ 4.6\% 增の 362,300 千 $\mathrm{t}$ となつてお り，その特徴としては米，英，西独の大手製鉄国の生産 が減少した半面, 日本, カナダ,イタリア, インド, 南 アフリカ，豪州などの新興製鉄国の生産上昇があげられ る.

米国は，対前年比 $1 \cdot 3 \%$ の減産になつたか，第 2 四半 期以降上昇傾向をたどつて扣り，これに反し英国は年間 を通じて緩慢な下降をたどり，西独は一進一退の推移を 示した.1962年の見通しについて世界の鉄鎆業は米国の 景気動向に注目しているが, 米国の 1962 年の粗龬生産 はかなりの増産になるものと予想されている．西欧諸国 は概ね 1961 年の横ばいで推移するものとみられている か，年末近くになつて上昇に転ずるとの見方が強い，乙 の場合 E E C 諸国と英国とは経済の動向に差があり, E E C 諸国の立直りにくらへ英国はやや掘れるるのとみ られている.

1961年に打ける世界各国の粗鎆生産高は次のとおり， (単位 $1,000 \mathrm{t}$ ，カッコ内は前年比)
（1）米 国 88,900(1.3\%减)
(2) $y$ 連 $71,700(0.0 \%$ 減)
(3) 西 独 $33,600(9 \cdot 8 \%$ 減)
（4）日 本 $28,200(27 \cdot 6 \%$ 增)
(5) 英 国 $22,400(9 \cdot 3 \%$ 減)
(6) フランス 17,600 (10・7\%增)
（7）中 共 $18,100(1.6 \%$ 減)
（8）イタリア 9,000 ( $9 \cdot 8 \%$ 增)

(1. 17. 日刊工業)

\section{戸畑第 2 転炬工堨完成}

八幡製鉄は, 戸畑第 3 高炉（公称日産 2 千 t, 3 月 22
日火入れ予定）の関連設儲として， 35 年 10 月から総 額 66 億円き投し戸畑第 2 転炉工場さ建設していたか， この程ほほ完成, 月末までに最終的な仕上げ工事さ行な つたあと，2月1日から試験操業さ開始する。

同工場の $130 \mathrm{t}$ 純酸素転炉（ 2 基）は，川鉄千葉の 150 $\mathrm{t}$ 転炬（4 月完成予定）上り若干容量は小さいか⿱，月間 12万 $\mathrm{t}$ の製銅能力をもつものと期待されている.

また同工場は，転炉ガスき然料あるいは化学原料とし て利用するため同社の特許による転炉ガス回収装置を設 備しているか，同装置は 2 月から碇㗢する予定で，当分 は煙乫上部で回収した転炬ガスな燃焼させるが，3月中 旬からボイラ一用然料として利用するためガスホルダー 亿睁蔵する。

\section{川鉄千葉の $150 \mathrm{t}$ 転炉}

川崎製鉄千葉製鉄所认建設中の $150 \mathrm{t}$ 転炣は，1号炻 の完成がきたる 4 月 20 日でろと决まり，目下インゴッ ト・ケースなど造塊に必要な隼储がととのられてい る. てれに引き结き 2 号炉は 7 月完成し，以後 2 基整備 の 1 基常時操業で, “高炉一転炉”の一貫生産態势には いるが，現在の $150 \mathrm{t}$ 平炉はそのままの作業態勢でのぞ み，転炉の増産分に比例して真合工場の平炉操業导漸娍 する方針である。

な打莫合工場は，現在 8 基整備の常時 $8 \sim 7$ 基操業 （1基 $100 \mathrm{t}$, 他 $50 \mathrm{t}$ ) こ，鎆塊 $3 \cdot 8 \sim 4 \cdot 0$ 万 $\mathrm{t}$ 空生産し ている. (1. 20. 鉄鋼新聞)

和歌山製鉄所の薄，厚板コンバインドミル完成

住友金属工業は，和歌山製鉄所に建設中のわが国では じめての薄, 厚板コンパインドミルがこの程完成, 2 月 1 日から試運転さ開始し, 鋼板部門に本格進出するとと になつた。この運転には，技術指導さ受けている米国の ショーンズ・アンド・ラフリン社から技術者 4 名が来日 して立会うことになつて拈り，3月に月産 2 亿千 $\mathrm{t}$ の 試作，4月以降年産 40 万 $\mathrm{t}$ ベースで主産さ行ない，来 春和歌山の第 2 高炉完成以降は年産 100 万 $\mathrm{t}$ ていどのべ ースでいきたいとしている.

このコンバインドミルは最新鋭のもので，iラインで 薄板から厚板まで一貫して流れるような仕組みになつて 打り，12・7 mm(1/2 インチ)までの厚さのものたコイル にできるという画期的なもの.

なお設䜤資金は約 100 億円，能力としては年産 200 万 $\mathrm{t}, 2 \mathrm{~m}$ 幅で厚さ $1 \cdot 2 \mathrm{~mm}$ から $25 \cdot 4 \mathrm{~mm}$ までの䔦,中， 厚板の生産が可能といわれる. (1.24. 日刊工業)

\section{世界最大の 200t 電気炉完成}

大同製鎆は，中部鋼鈑向け世界最大の $200 \mathrm{t}$ 電気炉写 同社高蔵製作所で製作中であつたかての程完成した。大 同製鋼では，昭和 27 年に米国のレクトロメルト社との 間海㫣炉製作に関して技術提携む結んでいらい，こん どのダイドー・レクトロメルト式電気炉の完成で 100 号 基目となる.

大同製鋼は，ての世界最大の電気炣学 3 月末までに中

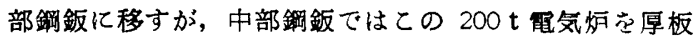


工場に見合う製鋼設備として本社工場内に設置し，4月

1 日に火入れるすることになつている.

完成したダイドー・レクトロメルト式 $200 \mathrm{t}$ 電気炻は 溶解量 $200 \mathrm{t}$, 炉毅内径 $7 \cdot 62 \mathrm{~m}$, トランス容量 4 万 $\mathrm{K}$. V.A, 1 次電圧 2 万 V, 2 次電圧最高 $700 \mathrm{~V}$ (最低 220 $\mathrm{V}, 17$ タップ $30 \mathrm{~V}$ おき) アンプリダイン $\mathrm{GE}$ 社製. 使 用電極 24 インチとなつている. これまで世界最大とい われているものは米国のリパブリック社（オハイオ州） などに $200 \mathrm{t}$ 電気炉 7 基が設置されている. しかしての 7 基の電気炉は炉殼内径が $7 \cdot 2 \mathrm{~m}$, トランス容量か子 $3 \cdot 6$ 万 K.V.A. となつている.

この炉の特徽としては溶接構造て採用し炉体構造を軽 くしていることなどとされるか，同哣にはかくはん装膡 を取付けるようになつている，従来の電気炉でかくはん 装置の取付けが可能であつたのは $150 \mathrm{t}$ 電気炉までであ り，200t 炬にかくはん装置て取付けるのははじめてで ある.

(1.22. 日刊工業)

\section{富士鉄広畑大形，龟磁銅板工場の建設}

富士製鉄広畑製鉄所は，36年度から 5 力年計画で第 3 次合理化計画さ進めているが，製品部門の骨格である大 形工場と電磁鎆板工場の新設工事が計画通り進められて いる. 両工場はいずれも新製品開発のため建設されてい るもので，大形工場は所要資金が 177 億円，電磁鎆板工 場は 109 億円というマンモスぶり，設備投資抑制で工事 のずれが心配されていたが, 両工場建設のため重点的に 設備投資をするという方針で，大形工場は9月末に，奄 磁鎆板工場は今年中にそ机ぞれ第 1 期工事を完成する。

第 3 次合理化計画は, 総額 54 億円を投じて, 第 4 高 炉の新設, 転炉の増設など大幅な生産力増強が計画され ているもので, 素材部門の強化に先行して, 製品部門の 建設を進めることになつているもの.（2．1．日刊工業）

\section{鹿カス処理装羁付きの転妒}

川㥓重工業は,このはど純酸素上吹き転炬排出ガス処 理装置について，フランスのカッフル社と乙種技術提携 を結び，近く東海製鉄向けに同装置をつけた転炉（公称 能力 $120 \mathrm{t}$ ） 2 基の製作にはいる。これは転炉から出る 一酸化炭素を非然焼ガスのまま回収するもの.

従来転炉廃ガスは，然やして熱を動力源に用いており $100 \mathrm{t}$ 以上の大型転炉では大がかりな廃熱ボイラーを併 設する必要があるが，イルシッド・カッフル方式による 同装置では，(1)ガス処理施設がきわめて小型化され， 建設費も安いため，コストが廃熱ボイラーの $1 / 4$ です む. (2) 回収ガスなメタノールなど化学工業用の二次原 料に利用できる (3)転炣につきものの赤い煙を防止でき るなどの利点があり，転炉の大型化傾向が強い折だけに 鉄銅業界の注目を集めている。

内容はガス回収輸送, フード内圧力の制御調整, ガス 温度制御調整, 保全の各装置から成り, 排ガスに大気が 混つていないよう可動スリープと過熱蒸気（イルシッド 方式）扣よび圧力制御（カッフル方式）を併用，外気を 遮断しているのが特色，炉体と同装置を合め 2 基分の総 工費 10 億円で，38年 2 月完成の予定.

\section{パキスタンに日パ合弁製釗所}

$$
\text { (1. 13. 日本経済) }
$$

パキスタンのカーン工業相は，1月24日，日本の援助 で東パキスタンのチッタコンに同国最初の製鎆所を建設 するととになつたと発表した。同製鋼所の建設霬は13億 ルピー(約 2600 万ドル)以上で，さきのパキスタン債権 国会議で日本が申入れた 2000 万ドルの対パキスタン援
助額のうち約 300 万ドルが当てられ，日本の製鉄会社 (神戸製銅所が主契約者)が資本参加する．同工場の生産 能力は鋼塊年間 10 万 $\mathrm{t}$.

(1. 26. 朝日新聞)

\section{日本最大の鉱石専用船起工}

三菱造船は，1月23日長崎造船所で千代田鉱石輸送加 ら受注した鉱石専用船 $(51,100$ 重量 t ) の起工式を行な う. 同船はわが国の鉱石専用船では最大のもの, 同船の 進水は 5 月下旬, 完成は 8 月末の予定で, 成完後は三菱 商事と用船契約を結び，米国のロングビーチ，チリから の鉄鉱石輸送に就航する. 同船のおもな仕様はつぎの通 り,

$$
\text { ○長さ } 214 \mathrm{~m} \text { ○幅 } 31 \mathrm{~m} \text { ○速力 } 16.5 \text { ノット }
$$

(1. 23. 日本経済)

\section{理研厈み測定器を試作}

理化学研究所では，かねて鍮の焼入れと浸炭層の厚さ を非破壊的に正確に測定できる厚み測定器の試作を進め ていたが，てのはどその第 1 号機が完成した。焼入れゃ 浸炭した銅材は, 工作機械をはしめ一般はん用機械, 電 気，車両機械関係などに現在広く使用されているか，乙 れまで非破壊的に簡単に測定できる計器がわが国はもと より外国にも全くなかつたため, 現品を破壊し, 肉眼や 顯微鏡による観察で厚みさ決定するという不便な方法が とられ量産の大きな障害となつていた．同所ではてうし

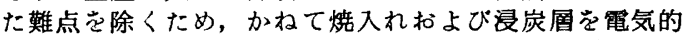
亿測定する基礎研究さ進め, 数年前にこれらの厚さき非 破壊的に測定できる方法さ確立（特䝠昭32-22805）した ので, 現場向きの厚み测定器の試作研究ふ引引つづき行 なつてきたもの. この方法とは，高周波表皮作用を利用 したもので, 高周波電流の流れているコイルさ焼入れあ るいは浸炭風に垂直に接触させると，その表皮作用によ り表面の厚さに比例して,コイルに流れる電流值が変化 する.これによつてコイルに直列に接続した電流計の指 示が変り, 厚さき簡単に知るととができるという原理に もとゔくものである.

\section{大同学團工業短大 4 月に開校}

大同製鋼は，同社外郭団体の学校法人大同学園に，本 年 4 月から工業短期大学を開設するととになり, かねて 文部省に設立認可申請中であつたが，旧ろう大学設置審 議会の番議を通過, 認可か内定したので, このはどその 内容が同短大学長錦織清治工博（同学園理事長，大同製 鋼技師長兼務）加ら発表された。とくに同短大は産業界 から要望の强い中堅現場技術者の養成さ目的としたもの で，また業界の研究委託による技術研究と開発を重視し ようとする点が注目される。

発表によると, 同短大は当初機械科 1 学科(定員80名) からスタートし, 漸次電気, 金属の諸学科を増設しよう というるの, 教育内容は修業年限が昼間 2 力年で, 生産 機械工学と生産技術の教育に重点をおくととになつてい る. とくに同短大は産学協同悬体化し, 地元産業界の 発展に寄与しょうという方針で，ての一環として産業界 加ら委託学生觉受入れ(年間約 40 名), 一般大学生と同一 の教育を施す制度を設けている。

さらに付属研究所な設圈し，産業界と委託研究や技術 者教育などを通じて地元業界との密接な協力体制さ打出 す構想をもち，とりあえず 37 年度内に燃焼工学研究所 計算センター觉設置したい考えで，また発明を工業化す る開発研究所を設け埋れた発明を開発しようという構想 もあり，私立短大としては古実した内容をもち，今後の 発展が期待されている。

(1. 13. 日刊工業) 